\title{
DETERMINATION OF FACTORS RESPONSIBLE FOR THE CHANGE IN VEGETAL COVER IN KATSINA TOWN
}

\author{
A. S. Mmaduabuchi, *Y. Bello and A.Yaro \\ Department of Geography and Regional Planning, Federal University Dutsin-Ma, Katsina State, Nigeria \\ ${ }^{*}$ Corresponding Author's Email: belloyusuf21@yahoo.com, +2348168121382
}

\begin{abstract}
The study examined the factors responsible for change in vegetation cover between 1999 and 2019. Decadal data for climatic variable (rainfall and temperature), Landsat satellite images and population data of 1999, 2009 and 2019 were used. Land use/Land cover Change Detection, linear time series and Spearman rank order correlation analysis were used. The results revealed that the extent change between (1999-2009) and (2009-2019) for built-up, vegetation and bare surface were; $(+91.66,+276.41),(-4.06,-40.42)$ and $(-27.44,-$ $23.5)$ respectively. There were increasing trends in the built-up environment, population growth and rainfall at the rate of $\left(19.3 \mathrm{~km}^{2}\right.$ per- $\left.{ }^{10}\right)$, (110116 persons per- $\left.{ }^{10}\right)$ and $\left(231.5 \mathrm{~mm} \mathrm{per}{ }^{10}\right)$ respectively. There were decrease trend of temperature and vegetation cover at the rate of $\left(-1.15^{\circ} \mathrm{C}\right.$ per- $\left.{ }^{10}\right)$ and $\left(-19.3 \mathrm{~km}^{2}\right.$ per- $\left.{ }^{10}\right)$ respectively. Negative relationship exist between population growth $(\mathrm{r}=-0.938)$, built up $(\mathrm{r}=-0.987)$, rainfall $(\mathrm{r}=-0.982)$ and vegetation cover, while positive relationship exist between temperature $(\mathrm{r}=0.965)$ and vegetation cover. The study conclude that temperature is the major factor influencing the loss in vegetation cover, rapid population growth and urban expansion were experienced during the study period. The study recommend five (5) trees should be planted per built-up structure in order to create more carbon sink and to improve vegetal resource which were affected by human activities and changing climatic variables.
\end{abstract}

Keywords: Population Growth, Climate Change, Vegetation, Satellite Imageries.

\section{INTRODUCTION}

Urban vegetation are affected by both natural and anthropogenic factors. The natural factors include changes in the climatic variable such as rainfall, sunlight and temperature while the anthropogenic factors include increase in human population, industrialization and urbanization which were influenced by natural increase in population and migration. Combination of these factors simultaneously affect the health, quality and distribution of vegetation in the urban environment Urban vegetation is affected by many factors, which include; climate, biophysical feature of soil, anthropogenic disturbances (Huang, Xu, Yang, and Shi, 2009). According to Idris et al (2019) human activities changes the natural state of the environment into different forms which include; Settlement, Urbanization, Industrialization. Growing population is unconnected to some environmental challenges (Maier, 2015) and negative relationship between increase in population and environmental degradation (Okechi, 2017).

United Nation, (2007) projects that by the year 2050, over $70 \%$ of the human population will be living in urban environment. More than $54 \%$ of the world's total population were living in cities, and an estimated $66 \%$ of them will occupy urban centers by the year 2025 (UN 2014) after Shirazi, and Kazmi, (2016). The urban population growth in Nigeria has change from less than seven (7\%) urban in the year 1931 to $(42 \%)$ in the year 1991 which is projected to reach $(61.6 \%)$ by the year 2025 (Onibokun and Faniran, 1995) after Gadiga and Galtima (2017).

Continuous decrease in vegetative/green cover in cities were due to rapid population growth and consequent urbanization which took over green areas and agriculture lands (Shirazi and Kazmi, 2016). The natural increase in birth rate and migration stimulate growth of population in urban centers because of better social amenities, infrastructures and availability of industries which attract increase in population (Kane, 2018). Due to growing population, more urban infrastructure need to be put in place to meet the growing population at the expense of the natural vegetation. Urbanization affect the ecological processes, local climate and human health in urban areas by changing the vegetation phenology (Ren, He, Huang, and Zhou 2018).

Spatial distribution of the major vegetation types at the global scale is influenced by climate, and its effect varies at the regional scale (Brovkin, 2002).Temperature is an important factor affecting vegetation phenology. The variation of the same species is influence by uneven distribution of temperature (Huang et al., 2009). Moderate increase in temperature result to increase in vegetation density and carbon sequestration potential (Bachelet, Neilson, Lenihan, and Drapek, 2001).

The inter-dependency between vegetation and climate in subtropical deserts and semi deserts is a function of precipitation. The amount of precipitation received and surface albedo determines the vegetation cover and bare surfaces (Brovkin, 2002). The effects of climate change on vegetation is as a result of the changes in rainfall, temperature, microbial activities, nutrient cycles and changes in precipitation affects the moisture regimes (Ali, 2012).

Rapid population growth and changes in climatic variables are 
contemporary issues in the developing country like Nigeria and Katsina town in particular. Human activates like deforestation are ongoing in order to create land for agriculture, residential and infrastructural purposes. Vegetation were cleared for various reasons resulting to lost in the carbon sink which eventually lead to global warming and later cause climate change. The resulted impact include increase in temperature, decrease in rainfall, loss of floral, drought and sometimes heavy rainfall will cause flooding and stunted plants. The study aims at assessing the factors responsible for the change in vegetal cover in Katsina urban area.

\section{Study Area}

Katsina town is located between latitude $12^{\circ} 08^{\prime} \mathrm{N}$ and $10^{\circ} 19^{\prime} \mathrm{N}$ of the equator, and longitude $7^{\circ} 32^{\prime} \mathrm{E}$ and $7^{\circ} 51^{\prime} \mathrm{E}$ of Greenwich
Meridian Figure 1. Katsina town is capital of Katsina state. The town has a total population of 222,644 National Population Commission, (NPC, 2006). The vegetation was largely modified because of many years of bush clearing/burning, cultivation and fuel wood extraction. The town is characterized by both hot and dry seasons. The temperature here average is $26^{\circ} \mathrm{C}$ and the annual rainfall average is $600 \mathrm{~mm}$. The rainfall last for six (6) month which starts around May to October, and dry seasons usually occur November to April (Olofin, 2014). The economic activities of the people include: Trading, Farming, Welding, livestock Rearing, Carpentry, and Civil Servants. However, there are quite a number of economic activities such as blacksmith, laborers, food vendors, tie and dye and other technical activities that serve as economic base of the people.

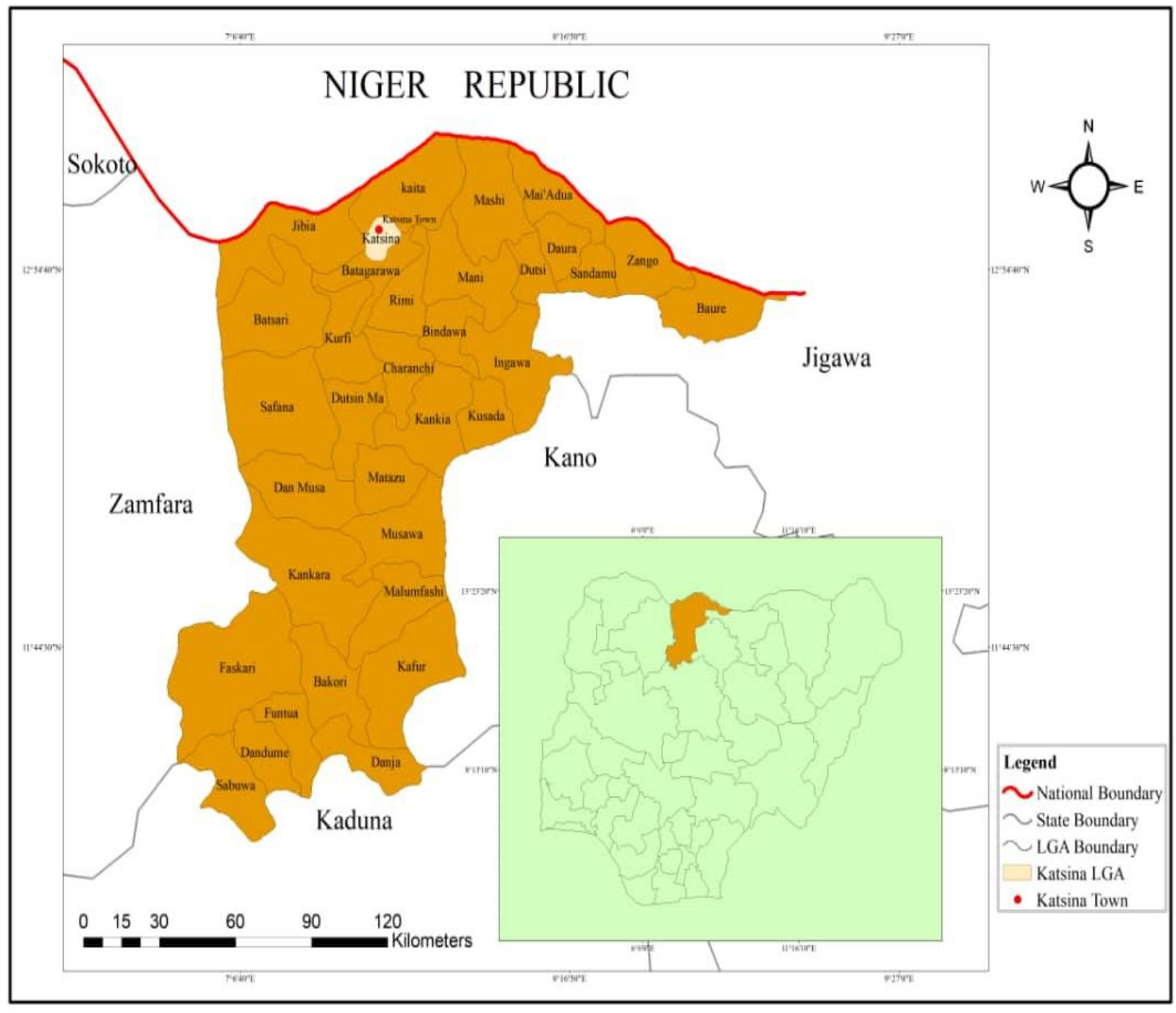

Figure 1. Map of the study area

Source: Katsina State Ministry of Land and Survey

\section{MATERIALS AND METHODS}

The data for this study were sourced from National Population Commission (NPC), Nigerian Meteorological Agency (NIMET) and Kaduna Geographic Information Science (KGIS). Population data, Climatic variable (Rainfall and
Temperatures) and Satellite imageries for Katsina town specifically for 1999, 2009 and 2019 were used. Data for the change in vegetation, bare surface and built up areas were derive from land use/land cover change detection analysis.

Linear time series analysis was used to detect the pattern of 
annual rainfall, temperature, population, build up and trends, both annual rainfall and temperature from (1984 vegetation cover. In order to identify variation within the 2014).

$\mathrm{Y}_{\mathrm{t}}=\mathrm{a}+\mathrm{bt}+\mathrm{e}_{\mathrm{t}}$

Where $\mathrm{Y}_{\mathrm{t}}=$ the amount of rainfall

$\mathrm{a}=$ intercept

$b=$ slope, which measures the rate of change of the variables with time $\mathbf{t}$

$\mathrm{e}_{\mathrm{t}}=$ random error component

The Spearman's rank order correlation coefficient (r) was used to determine the trend of the linear time series analysis either it is upward or downward. It is computed as:

rho $=1-\frac{6 \sum_{d} 2}{N\left(N^{2}-1\right)}$

Where $(r)$ is positive, it indicate upward/increasing pattern and where ( $r$ ) is negative, it indicates downward/ decreasing pattern of the time series. Spearman's correlation analysis was also used to determine the relationship that exist between change in vegetation cover which is (Dependent Variable) and factors influencing vegetation change which include; population, rainfall, temperature and built up areas as (Independent Variable).

Ground trothing exercise was first of all conducted to collect coordinate ( $\mathrm{x}$ and $\mathrm{y}$ ) data of the area using Handheld GPS in the study area. Two set of satellite images (Landsat 7 of 1999 and Landsat 8 of 2009 and 2019) were used for satellite image classification. Several bands and different wavelengths ranging from Visible, Near Infrared, Thermal and Microwave bands were used. Three (3) different satellite imageries were used under a supervised image classification and Change detection. Normalized Difference Vegetation Index (NDVI) and Normalized Difference Built-up Index (NDBI) were employed in the analysis. NDVI and NDBI were estimated using the following formulas:

$\mathrm{NDVI}=(\mathrm{NIR}-\mathrm{RED}) /(\mathrm{NIR}+\mathrm{RED})$

$\mathrm{NDBI}=(\mathrm{SWIR}-\mathrm{NIR}) /(\mathrm{SWIR}+\mathrm{NIR})$

The two (2) methods NDIV and NDVI were used because NDVI is best for vegetation and bare surface studies while

NDBI is best used for build-up studies. The outcome for both NDVI and NDBI were merge in to one image for each year and rescaled using geometric method. The results obtained were overlay to determine the extent of change for the variables under investigation for the study periods.

Landsat 7: NIR stands for band 4 and RED stands for band 3, while

Landsat 8: NIR stands for band 5 and RED stands for band 4 .

NDVI ranges from 0 to 1.

SWIR: Shortwave Infrared which stands as band 5 on Landsat 7 while band 6 on Landsat 8 .

Maximum Likelihood algorithm were used to classify the images into three (3) classes (Built-up Areas, Vegetation, and Bare surfaces). Erdas Imagine 2014 and ArcMap 10.3 were used in carrying out the analysis. Finally field validation exercise was carried out.

\section{RESULTS AND DISCUSSION}

Land Use /Land Cover Change Detection

The trend/changes of land use / land cover in Katsina town for the period of 20 years (1999-2019) is presented in (Table 1). The built up area have increase due to population growth. The vegetal cover which serves as resource to man have been cleared for different purposes such as industrial, residential, educational, recreational and administrative purposes.

Table 1: Land Use/Land Cover Dynamics for Katsina Urban Area 1999 - 2019

\begin{tabular}{llllcccc}
\hline $\begin{array}{l}\text { Land Use/Land } \\
\text { cover }\end{array}$ & $\begin{array}{c}1999 \\
\left(\mathrm{Km}^{2}\right)\end{array}$ & $\begin{array}{l}2009 \\
\left(\mathrm{Km}^{2}\right)\end{array}$ & $\begin{array}{l}2019 \\
\left(\mathrm{Km}^{2}\right)\end{array}$ & $\begin{array}{c}\text { Extent } \\
\text { Change } \\
(1999-2009)\end{array}$ & $\begin{array}{c}\text { \% } \\
\text { Change } \\
(1999-2009)\end{array}$ & $\begin{array}{c}\text { Extent } \\
\text { Change } \\
(2009-2019)\end{array}$ & $\begin{array}{c}\text { Change } \\
(2009-2019)\end{array}$ \\
\hline Built-up & 111.2 & 202.86 & 479.27 & +91.66 & 82.4 & +276.41 & 136.25 \\
Vegetation & 126.41 & 122.35 & 81.93 & -4.06 & 3.21 & -40.42 & 33.03 \\
Bare surface & 142.10 & 114.66 & 91.16 & -27.44 & 19.31 & -23.5 & 20.49 \\
\hline
\end{tabular}

Source: Authors Analysis (2020) + Indicate increase, - Indicate decrease

The extent of change for the first decade (1999-2009) for the Built-up, Vegetation and Bare surface were $+91.66,-4.06$ and 27.44 and their percentage change were $82.4 \%, 3.21 \%$ and $19.31 \%$ respectively. The extent of change for the second decade (2009-2019) for the Built-up, Vegetation and Bare surface were $+276.41,-40.42$ and -23.5 and their percentage change were $136.25 \%, 33.03 \%$ and $20.49 \%$ (Table 1). This finding is related to the result of Yaro and Abdulrashid (2017) observed a negative extend change of Vegetation (-49.12) and positive change in built up areas $(+113.98)$ but their bare surface $(+61.28)$ result does not agree with the findings of this work because it have negative values. Also Idris et al (2019) 
reported net change in bare surface (-375.45), vegetation $(+5456.1)$ and settlement/ built up $(+748.89)$.

In the year 1999, the over lay results revealed that built-up environment, vegetal cover and bare surface occupies 111.2 $\mathrm{km}^{2}, 126.41 \mathrm{~km}^{2}$ and $142.10 \mathrm{~km}^{2}$ with their respective percentages $(29.3 \%),(33.3 \%)$ and $(37.4 \%)$ respectively of the total classes (Table 1) and (Figure 2). This may be due to the fact that population pressure was not high then.

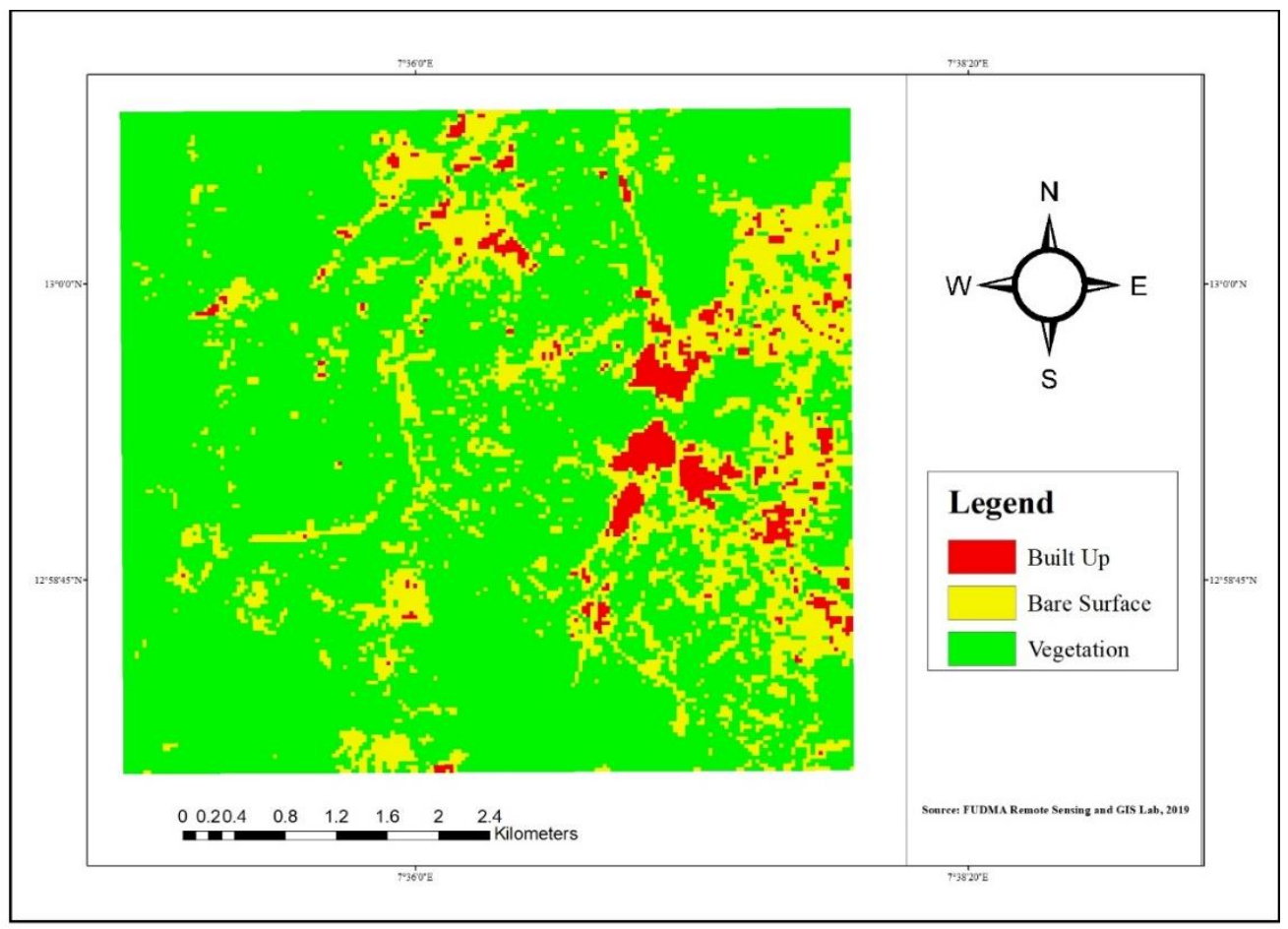

Figure 2: Land use/Land cover Distribution (1999).

Source: Supervised Image Classification (2020)

In the year 2009 , the vegetation cover decreased to $122.35 \mathrm{~km}^{2}(27.8 \%)$, built up areas increase to $202.86 \mathrm{~km}^{2}(46.2 \%)$ and the bare surface decrease to $114.66 \mathrm{~km}^{2}(26 \%)$. Due to the population growth, the spatial structures and facilities were erected to meet the need of the growing population. 


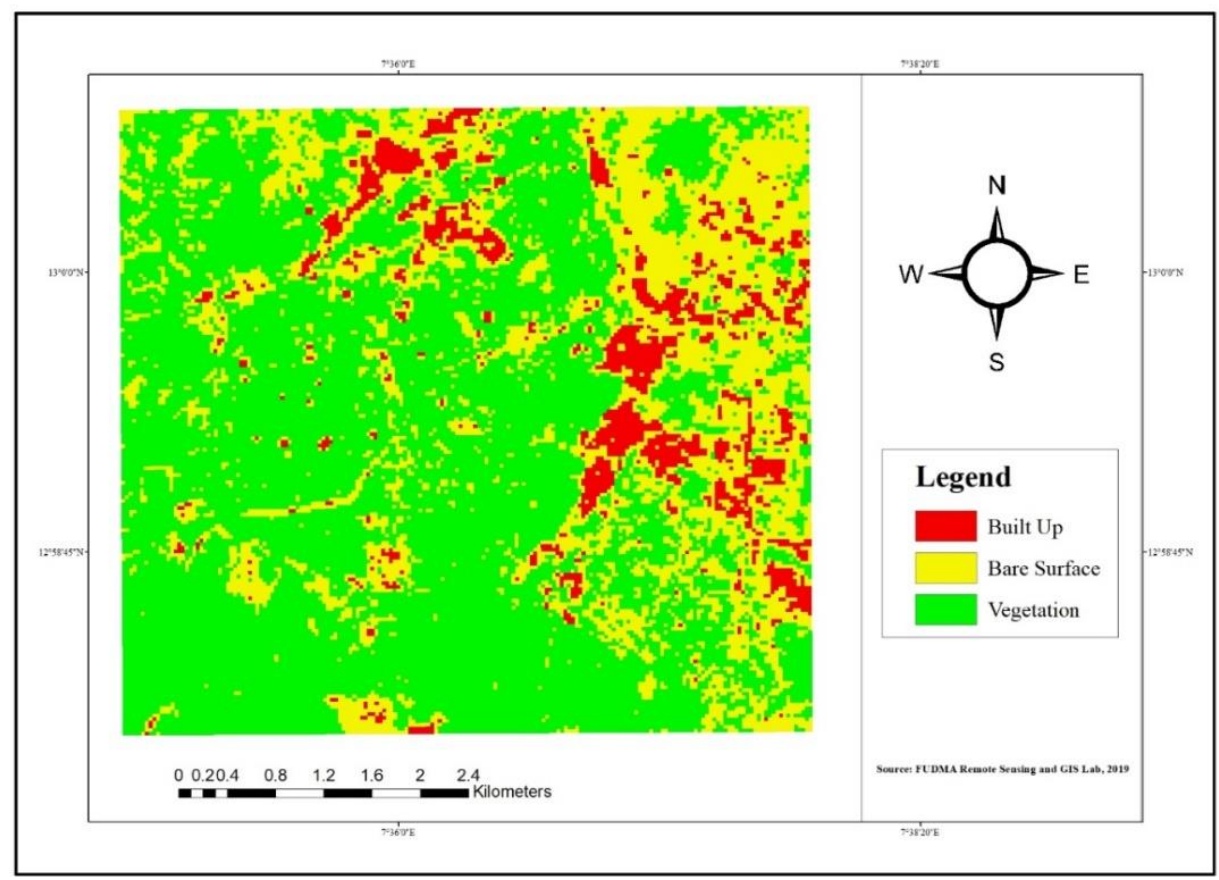

Figure 3: Land use/Land cover Distribution (2009).

Source: Supervised Image Classification (2020)

However, in 2019 there was a great decrease in vegetation covers to $81.93 \mathrm{~km}^{2}(12.6 \%)$ and there was rapid growth in built up areas with $479.27 \mathrm{~km}^{2}(73.5 \%)$ while the bare surface decrease to $91.16 \mathrm{~km}^{2}(13.9 \%)$ (Figure 4). This occurred due to tremendous increase in population growth which is estimated to be 488,150 persons. These populations exert pressure on vegetal resources especially the construction of basic and social facilities such as road, power station, health centers, recreational centers, religious, commercial, educational, administrative centers in the study area.

Furthermore, the continuous exertion of population pressure on vegetal covers result to the loss of carbon sinkers which helps to in regulating of air cycle. These may create room for generating more greenhouse gases (carbon dioxide) that are on the increase in the atmosphere and leading to global warming which subsequently results to climate change due to alteration of the climate system by man.

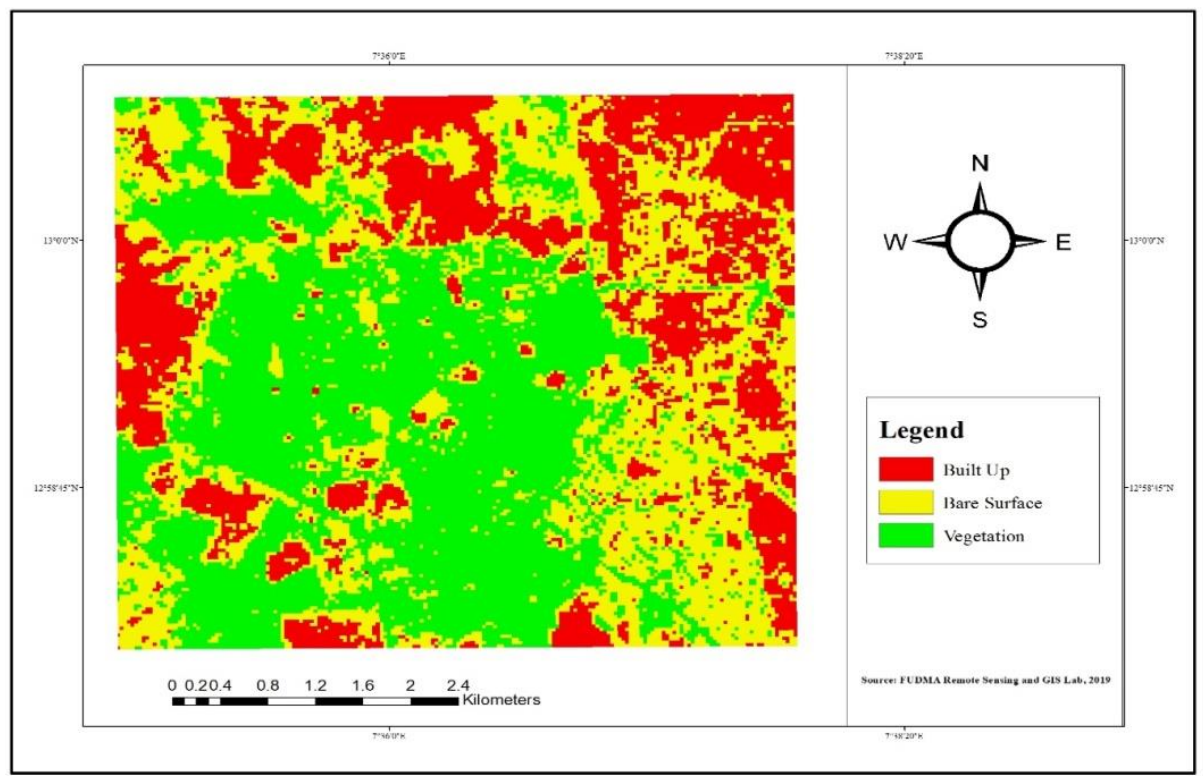

Figure 4: Land use/Land cover Distribution (2020).

Source: Supervised Image Classification (2020) 
Patterns of Rainfall, Temperature, Population, Built-Up and Vegetation

Decadal trend of population growth for Katsina town is on the increase which is attributes to early marriages and practice of polygamy. Based on 1991 census, the population for Katsina town was 210,758 people. The projection population for Katsina town in 1999, 2009 and 2019 were; 267,919 people, 361,642 people and 488,150 people respectively. The decadal population increase at the rate of (110116 people per $\left.^{-10}\right)$ and the coefficient of variations $(99.2 \%)$ presented in (Figure 5).

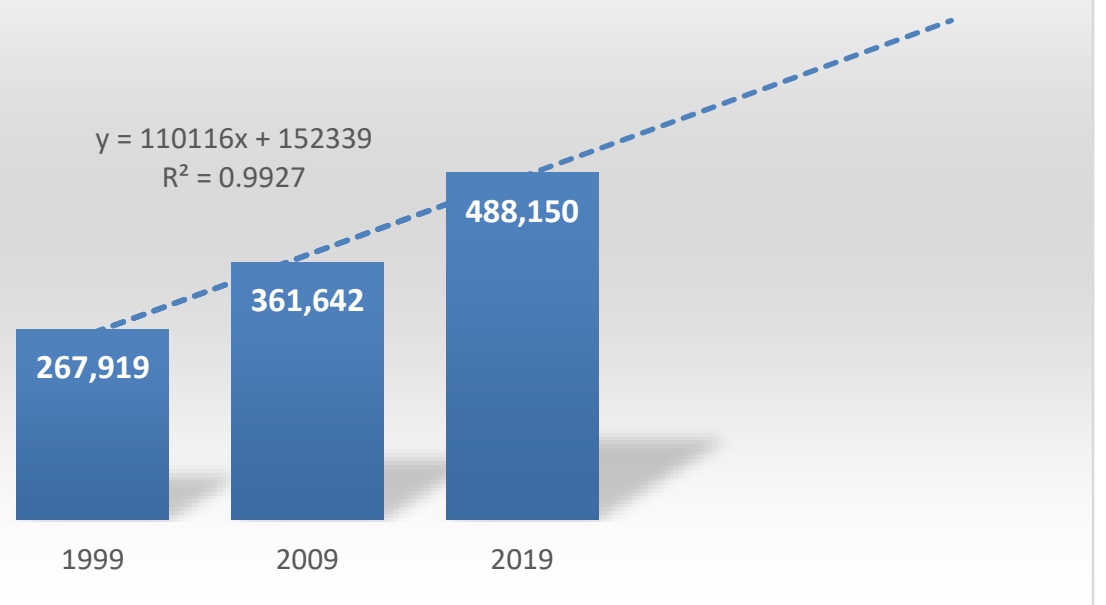

Figure 5: Decadal Trend of Population Growth (1999 - 2019) Source: Author Computation, 2020

There is a decreasing pattern of decadal mean temperature at the rate of $\left(-1.15^{\circ} \mathrm{C} \mathrm{per}^{-10}\right)$ and the coefficient of variation was (97\%) presented in (Figure 6). This result was in line with the findings of Bello, Adebayo and Bashir (2020) predicted a decadal decreasing trend of temperature in Billiri.

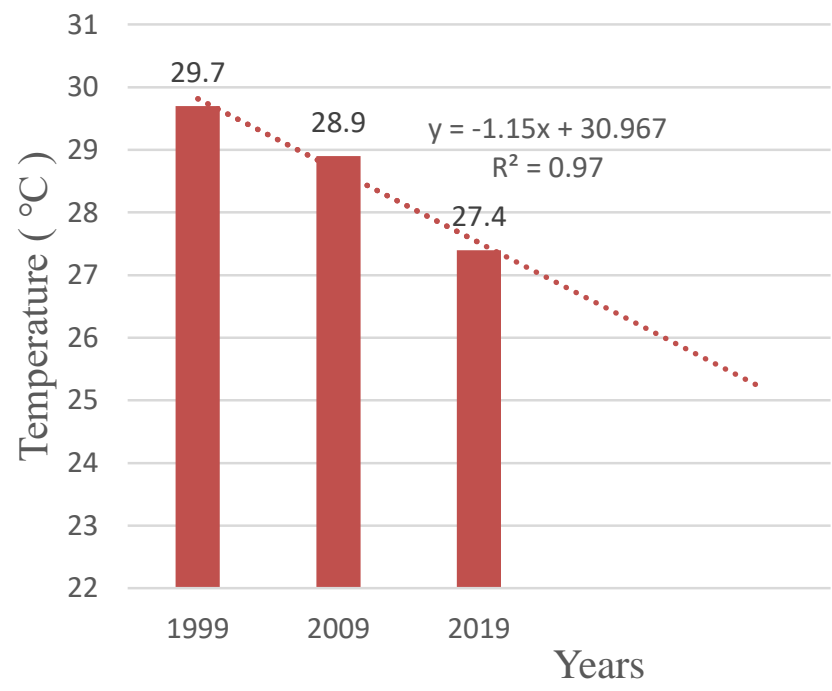

Figure 6: Decadal Trend of Mean Annual Temperatures Source: Author Computation (2020)

There was a decadal increasing trend of rainfall at the rate of $\left(231.5 \mathrm{~mm}\right.$ per- $\left.{ }^{10}\right)$. The coefficient of variation is $(93.8 \%)$. This relate with the findings of (Abaje Achiebo and Matazu , 2018) observed increasing trend of rainfall in Kaduna metropolis, and also (Bello et al., 2020) report an increasing trend of rainfall in Gombe town. This implies that the increasing rainfall in Katsina metropolis is in line with the current trends of rainfall within the urban centers. 


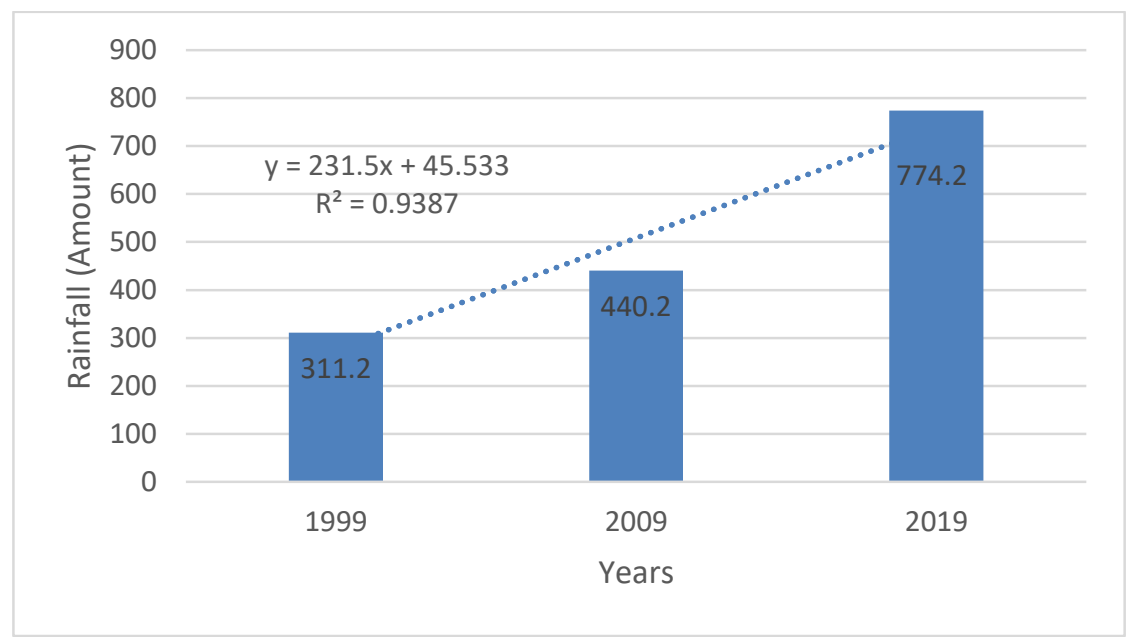

Figure 7: Decadal Trend of Annual Rainfall Totals in the study area Source: Authors Computation (2020).

The decadal trends of built up environment and vegetal cover were presented in (Figure 8). The built up environment was increasing from $(46.8 \%),(62.4 \%)$ and $(85.4 \%)$ in 1999,2009 and 2019 respectively. The increase in of built up areas in Katsina town was due to the increase in population as a result of the establishment of spatial structures such as residential facilities, recreational structures, tertiary and administrative facilities needed by this increasing population in Katsina town presented in (Figure 4). The vegetation cover decreases through the following trend $(53.2 \%),(37.6 \%)$ and $(14.6 \%)$ in 1999 , 2009 and 2019 respectively. There is decadal increase in the buildup environment is at the rate of $\left(19.3 \mathrm{~km}^{2}\right.$ per- $\left.{ }^{10}\right)$ and the coefficient of variation is $(98.7 \%)$ while the decadal pattern of vegetation cover shows a decreasing trend at the rate of $(-19.3$ $\mathrm{km}^{2}$ per- $\left.^{10}\right)$ and the coefficient of variation is $(98.7 \%)$. If the present trend continues, vegetation cover will decrease by ($193 \mathrm{~km}^{2}$ ) and the built-up environment will increase by (193 $\mathrm{km}^{2}$ ) in the next decade.

Similar findings like (Maina, et al., 2017), (Nwaogu, et al., 2017) and (Okosun, 2018) report that built up areas were increasing while vegetal cover were decreasing. The vegetation cover in Katsina town is decreasing as result of increase in built up environment and climatic factors.

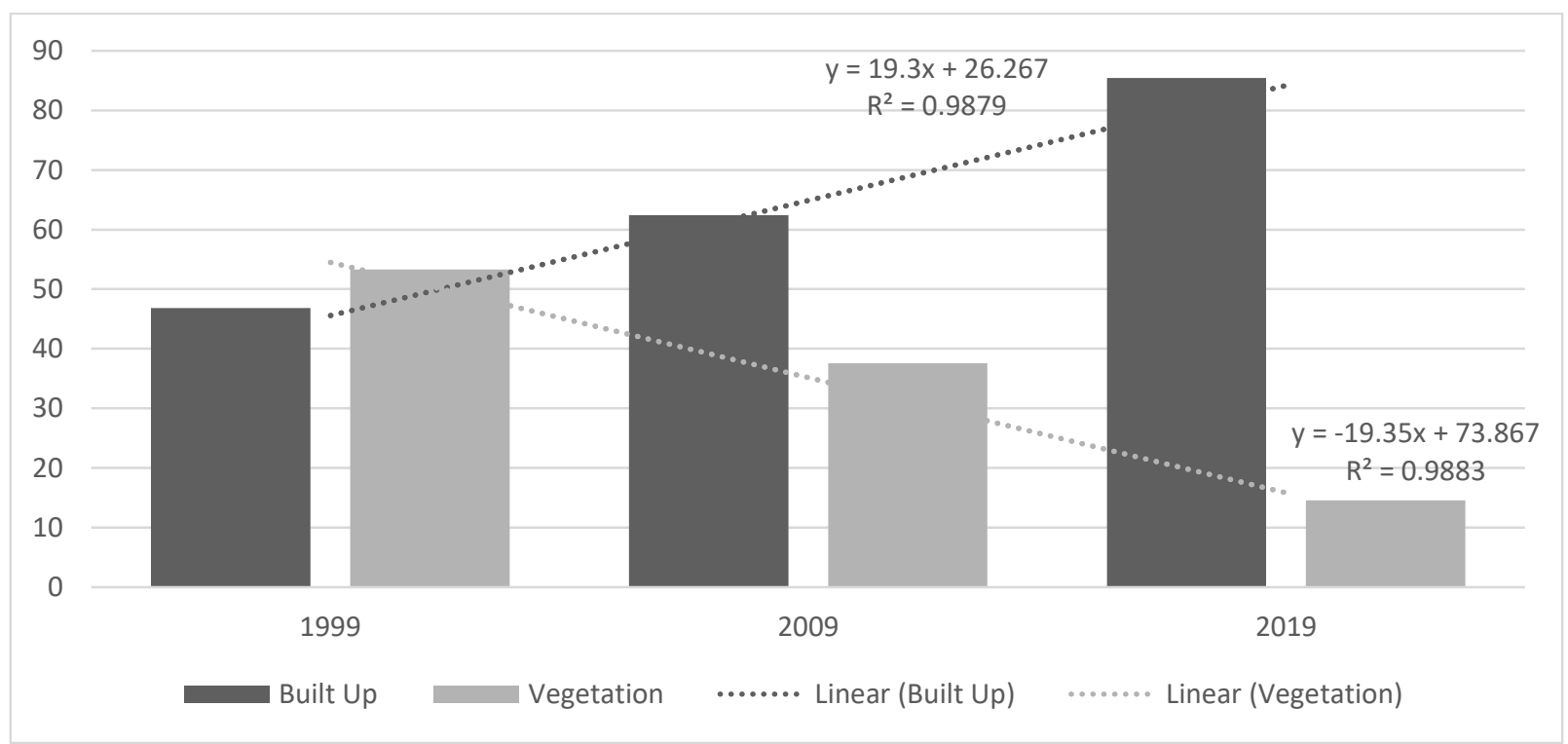

Figure 8: Decadal Trend of Built-up and Vegetation Cover in the study area Source: Authors analysis (2020).

Relationships between Climatic Factors (Rainfall and Temperature), Anthropogenic Factors (Build up and Human Population) and Vegetation Cover

The decadal data for population growth, temperature, rainfall, vegetation cover and built-up environment for the study period were presented in (Table 2). This data were used for the correlation analysis. 
Table 2: Variables for Factor Determination

\begin{tabular}{|c|c|c|c|c|c|}
\hline Years & $\begin{array}{l}\text { Population } \\
\text { (Persons) }\end{array}$ & $\begin{array}{l}\text { Temperature } \\
\left({ }^{\circ} \mathrm{C}\right)\end{array}$ & Rainfall (mm) & Vegetation $\left(\mathrm{km}^{2}\right)$ & Built-up $\left(\mathrm{km}^{2}\right)$ \\
\hline 1999 & 267,919 & 29.7 & 311.2 & 126.41 & 111.2 \\
\hline 2009 & 361,642 & 28.9 & 440.2 & 122.35 & 202.86 \\
\hline 2019 & 488,150 & 27.4 & 774.2 & 81.93 & 479.27 \\
\hline
\end{tabular}

Source: Authors computations, 2020.

Table 3 provides the correlation coefficient of decadal rainfall, temperature, built up area, population and vegetation for the study period.

Table 3: Correlation between Population, Temperature, Build Up and Vegetation Cover

\begin{tabular}{|l|l|r|r|r|r|}
\hline & & Population & Temperature & Rainfall & Buildup \\
\cline { 2 - 6 } & Pearson Correlation & -0.938 & 0.965 & -0.982 & -0.987 \\
\cline { 2 - 6 } Vegetation & Sig. (2-tailed) & $0.226 \mathbf{~ N S}$ & $0.170 \mathrm{NS}$ & $0.121 \mathrm{NS}$ & 0.101 NS \\
\cline { 2 - 6 } & $\mathrm{N}$ & 3 & 3 & 3 & 3 \\
\hline
\end{tabular}

Significant Level: * 10\%, ** 5\%, ***1\%, NS: Not Significant

Source: Authors Computation (2020)

The correlation analysis between change in vegetation cover and population reveal that there is a very high negative relationship of $(r=-0.938)$ between them and the P-value is (0.226), this information imply that there is not significant relationship between them. This result does not agree with the result of (Tobar, 2012) report that increasing population density trends have a strong direct correlation with natural environments (bare surface and vegetation) and (Jiang et al., 2017) noted that increasing population have a significant negative correlation with vegetation cover.

A very high positive relationship exist between change in vegetation cover and mean annual temperature $(r=0.965)$, the P-value is $(0.170)$, this means there is not significant relationship between them. There is a very high negative relationship between vegetation and annual rainfall totals is ( $r$ $=-0.982)$, while the P-value is $(0.121)$ which is not significant at $5 \%$. The relationship that exist between buildup area and the vegetation cover is $(r=-0.987)$ which is (very high negative) and the P-value is $(0.101)$ meaning not significant at $5 \%$. From the results of correlation analysis obtain, temperature is the major factor in influencing the change in vegetation cover. This result is in line with the findings of (Huang et al., 2009) noted that temperature affect the distribution of vegetation and Awuh et al., (2019) report that strong relationship exist between builtup and Temperature while Leilei, Jianrong and Yang, (2014) noted that vegetation has a greater correlation coefficient with rainfall than Temperature.

\section{CONCLUSION}

The study conclude that Katsina metropolis is experiencing rapid growth in human population and urban expansion per decade. Climatic variable (temperature) is the major factor influencing decline in vegetation cover. Increase in human population and human activities like urbanization have tendency to affect urban vegetation.

\section{RECOMMENDATION}

The study recommend that government should create shelterbelts/ forest reserved around the study area and enforce environmental laws regarding vegetation within the urban center. Trees should be planted around every buildup structure within the urban center in order to create more carbon sink and improve vegetal resource which was affected by human activities and changing climate.

\section{REFERENCES}

Abaje, I.B. Achiebo, P.J and Matazu, M.B. (2018). SpatioTemporal Analysis of Rainfall Distribution in Kaduna State Nigeria. Ghana Journal of Geography, 10 (1): 1-21

Ali, M. (2012). Effect of Climate Change Impact on Plant Biomass Growth. Springer, 2(3);29 - 31

Awuh, M. E., Japhets, P. O. , Officha, M. C., Okolie, A. O., Enete, I. C. (2019). A Correlation Analysis of the Relationship between Land Use and Land Cover/Land Surface Temperature in Abuja Municipal, FCT. Nigeria Journal of Geographic Information System, 1(11):53

Bachelet, D., Neilson, R.P., Lenihan, J.M., Drapek,R.J. (2001). Climate Change Effect on Vegetation Distribution and Carbon Budget in the United State. Ecosystems, 4:164-185

Bello, Y., Adebayo, A. A. and Bashir, B. A. (2020). Analysis of Rainfall and Temperature Changes in Gombe State, Nigeria. FUDMA Journal of Sciences, 4 (1): $632-646$

Brovkin, V. (2002). Climate -Vegetation Interaction. J.Phys, 4(12):52-55

Huang, Q., Xu,H., Yang,X., and Shi,P (2009). Study of Impacts of Urbanization Process on Phenology Using Multisource Satellite Data ASPRS 2009. Proceedings of the 2009 Annual Conference of Baltimore, Maryland, pp: 1-6

Idris, S., Mahmood, M.M., James, G.K., Olojo, O.O., Isah, A.A., and Mustapha, S. (2019). Land Use/Land Change Dynamics of Katsina State, Nigeria. International Journal of Advanced Research and Publications 3(8):19-23

Jiang, M., Tian, S., Zheng, Z., Zhan,Q., and He,Y. (2017). Human Activity Influences on Vegetation Cover Changes in Beijing, China, from 2000 to 2015. Remote Sensing 9 (271) :1 
Kane, M. (2018). Environmental Sciences: Human Population Growth. A Brief Review. Africa Geosocial. 6 :71-82.

Maier, D. (2015).The Great Myth: Why Population Growth does not Necessarily Cause Environmental Degradation and Poverty. The Public Sphere: 150-158

Maina, B., Sule, S., Amin, D. C., Kollos, N. P., and Dayil, D. C. (2017). Land use/Land Cover Change Detection of Gombe Metropolis, Gombe State, Nigeria. Academia Journal of Environmental Science Academia Publishing 5(6):2-4

National population commission (NPC). (2006), Report on 2006 National Population Census.

Nwaogu, C., Okeke,O.J., Fadipe,O.O., Bashiru,K.A. and Pechanec,V. (2017). Is Nigeria losing its natural vegetation and landscape? Assessing the Land Use-Land Cover change Trajectories and Effects in Onitsha Using Remote Sensing and GIS. Open Geosci, 1(9) : 707-718.

Okechi, O.S. (2017). Population and Environmental Policies in Nigeria: A Part of the Whole of the Global Environmental and Population Challenges Journal of Research and Development $6(1): 2$.

Okosun, O.S. (2018). Urban Landuse Extension on Agricultural Land Use in Tunfure, Gombe State of Nigeria. International Journal of Social Sciences and Conflict Management 3 (2) : 45 .
Olofin, E.A. (2014). Fluvial Geomorphology. A lecture note series for GEO 8314. Department of Geography, Bayero University, Kano-Nigeria.

Otto, G. (2008) Urbanization in Nigeria: Implications for Socio-Economic Development. Journal of Research in National Development, 6 (2):3.

Ren, Q., He, C., Huang, Q and Zhou, Y. (2018). Urbanization Impacts on Vegetation Phenology in China Remote Sensing,, 10 (1905): 2.

Shirazi,S.A., and Kazmi,J.H. (2016). Analysis of SocioEnvironmental Impacts of the Loss of Urban Trees and Vegetation in Lahore, Pakistan: A Review of Public Perception. Ecological Process, 5(5):1-5.

Tobar, I.M. (2012). Geostatistical Analysis of Land Use/Land Cover Changes and Population Growth Trends in the Komadugu-Yobe River Basin In Nigeria, M. S. Thesis, Missouri-Kansas City University.

Yaro, A. and Abdulrashid, L. (2017). Land use and Land Cover Changes in a Semi-Arid Region of Katsina state, Nigeria. Dutse Journal of Pure and Applied Sciences (DUJOPAS) 3 (1):436 